\title{
STRATEGI DALAM MEMAJUKAN INDUSTRI KREATIF DAN PENGEMBANGAN EKONOMI LOKAL SEBAGAI DAYA TARIK WISATA (Studi Pada Kesenian Jaranan di Kota Kediri)
}

\author{
Bothy Dewandaru \\ Fakultas Ekonomi, Universitas Kadiri \\ Bothy@unik-kediri.ac.id \\ Nining Purnamaningsih \\ Fakultas Ekonomi, Universitas Kadiri \\ Nining1958@yahoo.com
}

\begin{abstract}
Abstrak
Penelitian ini dibuat untuk melihat seberapa besar pemanfaatan industri kreatif di Kota Kediri dan pengembangan ekonomi lokal terutama pada kesenian Jaranan yang sudah menjadi salah satu ikon Kota Kediri. Industri kreatif yang didasari pengembangan ekonomi lokal akan lebih mendorong munculnya potensi-potensi ekonomi baru dan mampu memberdayakan tenaga kerja lokal yang pada akhirnya akan meningkatkan perekonomian Kota Kediri. Penelitian ini menggunakan metode analisis data deskriptif kualitatif, dimana metode ini digunakan untuk menjelaskan suatu femomena yang terjadi. Hasil penelitian menunjukkan bahwa kesenian Jaranan memiliki daya tarik besar di masyarakat Kota Kediri, sehingga di setiap pertunjukkan banyak pedagang kecil yang berjualan serta semakin bertambahnya pengrajin perlengkapan Jaranan yang hidup dari daya tarik kesenian Jaranan.
\end{abstract}

Kata kunci : Industri kreatif, pengembangan ekonomi lokal, Jaranan

\section{Pendahuluan}

Di Indonesia ekonomi kreatif dipahami sebagai industri yang berasal dari pemanfaatan cadangan sumber daya yang bukan hanya terbarukan, bahkan tak terbatas, yaitu ide, gagasan, bakat atau talenta dan kreativitas. Industri tidak dapat lagi bersaing di pasar global dengan hanya mengandalkan harga atau kualitas produk saja, tetapi harus bersaing berbasiskan inovasi, kreativitas dan imajinasi. Menurut Departemen Perdagangan, (2008) ada beberapa arah dari pengembangan industri kreatif ini, seperti pengembangan yang lebih menitikberatkan pada industri berbasis: (1) lapangan usaha kreatif dan budaya (creative cultural industry); (2) lapangan usaha kreatif (creative industry), atau (3) Hak Kekayaan Intelektual seperti hak cipta (copyright industry).

Pengembangan sektor pariwisata didukung Inpres No 16 Tahun 2005 tentang kebijakan pembangunan kebudayaan dan pariwisata, terdapat tujuh kebijaksanaan yang tercantum yaitu: promosi digencarkan, aksebilitas diperlukan, mutu produk dan pelayanan ditingkatkan, kawasan wisata dikembangkan, wisata bahari digalakkan, SDM ditingkatkan, sadar budaya, dan sapta pesona dibudayakan ( Musanef, 1995).Pengembangan ekonomi 
lokal berbasis seni pertunjukkan memiliki potensi untuk membuat desa wisata yang berbasis seni. Kegiatan pariwisata dengan memanfaatkansumberdaya setempat mulai dikembangkan mendasarkan pada tujuan ekonomiberkelanjutan, mendukung upaya-upaya pelestarian lingkungan, dan meningkatkankesejahteraan masyarakat setempat (Fandeli, 2001).

Kesenian Jaranan di Kota Kediri sendiri terdapat di setiap kecamatan dan jumlahnya cukup banyak. Jika potensi ini tidak dimanfaatkan oleh pemerintah daerah, maka lambat laun dampak ekonomi dari kesenian Jaranan akan menghilang seperti potensi lapangan pekerjaan. Pemerintah sebagai pembuat kebijakan belum memaksimalkan potensi kesenian Jaranan sebagai daya tarik wisatawan, kesenian Jaranan baru dimanfaatkan dalam kegiatan tahunan Kota Kediri, namun pertunjukkan secara berkala dan terjadwal belum ada.

\section{Rumusan Masalah}

1. Bagaimana pembangunan industri kreatif di Kota Kediri ?

2. Bagaimana penyerapan tenaga kerja dan pemanfaatan ekonomi lokal dalam kesenian Jaranan?

3. Bagaimana strategi dalampengembangan ekonomi lokal dan ekonomi kreatif pada kesenian Jaranan sebagai daya tarik wisata?

\section{TujuanPenelitian}

1. Untuk mengetahui pembangunan industri kreatif di Kota Kediri

2. Untuk mengetahui penyerapan tenaga kerja dan pemanfaatan ekonomi lokal dalam kesenian Jaranan

3. Untukmengetahui strategi dalampengembangan ekonomi lokal dan ekonomi kreatif pada kesenian Jaranan sebagai daya tarik wisata

\section{Pengembangan Ekonomi Lokal}

The World Bank (2001) menjelaskan proses ekonomi yang dilakukan bersama oleh pemerintah, usahawan, dan organisasi non-pemerintah untuk menciptakan kondisi yang lebih baik untuk pertumbuhan ekonomi dan penciptaan lapangan kerja di tingkat lokal.Helmsing (2001) Pengembangan Ekonomi Lokal (PEL) dapat didefinisikan sebagai proses di mana kemitraan antara pemerintah daerah, kelompok berbasis masyarakat dan sektor swasta yang didirikan untuk mengelola sumber daya yang ada untuk menciptakan lapangan kerja dan mendorong perekonomian dengan baik sebuah wilayah tertentu. Ini menekankan pengendalian lokal, dengan menggunakan potensi 
manusia lokal, kelembagaan dan kemampuan fisik.Pembangunan ekonomi lokal memiliki inisiatif memobilisasi pelaku, organisasi, dan sumber daya, mengembangkan lembaga baru dan sistem lokal melalui dialog dan tindakan strategis.

Fristia dan Navastara (2014) dalam penelitiannya yang berjudul "Faktor Penyebab Belum Berkembangnya Industri Kecil Batik Desa Kenongo Kecamatan TulunganSidoarjo" mengemukakan bahwa kebijakan yang dipandang tepat dan strategis dalam rangka pembangunan potensi wilayah adalah kebijakan pengembangan ekonomi lokal.

Pengembangan ekonomi lokal adalah suatu proses yang mencoba merumuskan kelembagaan-kelembagaan pembangunan di daerah, peningkatan kemampuan sumber daya manusia untuk menciptakan produk-produk unggulan yang lebih baik, pencarian pasar, alih pengetahuan dan teknologi, serta pembinaan industri kecil dan kegiatan usaha pada skala lokal.

Dalam perspektif pembangunan ekonomi lokal, interaksi antara pariwisata dan wilayah menjadi fundamental. Pariwisata telah menjadi salah satu industri yang paling penting. Hal ini didasarkan pada globalisasi dan perannya dalam perkembangan global, sedangkan dimensinya adalah lokal dan terhubung dengan jaringan lokal perusahaan. Model pembangunan ekonomi daerah, lembaga harus menyadari masalah dan risiko dari program yang diselenggarakan tidak baik dan intervensi berkelanjutan di wilayah tersebut.Intervensi pemerintah harus menyatakan rute untuk pengembangan ekonomi lokal, terutama untuk apa yang menyangkut keberlanjutan.

Pariwisata merupakan salah satu aktivitas ekonomi yang membantu daerah lokal untuk mengembangkan ke arah tujuan wisata. dengan adanya hal itu ada banyak efek yang terjadi, beberapa hal merupakan konsekuensi linear seperti munculnya hotel dan industri travel. efek positif yang mungkin terjadi adalah peningkatan kesejahteraan dan pertumbuhan ekonomi lokal, sedangkan efek lainnya yaitu menyangkut lingkungan dan konteks kultur sosial yang mungkin terpengaruh oleh adanya budaya baru dan gaya hidup (Pedrana, 2013).

\section{Ekonomi Kreatif}

Menurut Romer (1993), bahwa ide adalah barang ekonomi yang sangat penting, lebih penting dari objek yang sering ditekankan di kebanyakan model dan sistem ekonomi. Di dunia yang mengalami keterbatasan fisik ini, adanya penemuan ide-ide 
besar, yang juga diiringi oleh jutaan ide-ide kecil telah menjadikan ekonomi tetap tumbuh secara dinamis.

Ekonomi kreatif erat kaitannya dengan industri kreatif, namun ekonomikreatif memiliki cakupan yang lebih luas dari industri kreatif. Ekonomi kreatifmerupakan ekosistem yang memiliki hubungan saling ketergantungan antararantai nilai kreatif (creative value chain); lingkungan pengembangan (nurturanceenvironment); pasar (market) dan pengarsipan (archiving). Ekonomi kreatif tidak hanya terkait dengan penciptaan nilai tambah secara ekonomi, tetapi juga penciptaan nilai tambah secara sosial, budaya dan lingkungan. Oleh karena itu,ekonomi kreatif selain dapat meningkatkan daya saing, juga dapat meningkatkankualitas hidup Bangsa Indonesia.

Untuk mengembangkan ekonomi kreatif, diyakini bahwa kolaborasi antara pihak yang berperan dalam industri kreatif yaitu cendekiawan (intellectuals), bisnis (business), dan pemerintah (government) menjadi mutlak dan merupakan prasyarat tersendiri. Tanpa kolaborasi ketiga elemen itu, maka dikhawatirkan bahwa pengembangan ekonomi kreatif tidak berjalan selaras, efisien dan saling tumpang tindih. Hal ini karena setiap aktor memiliki peran yang signifika, namun juga memerlukan kontribusi dari berbagai pihak. Bentuk kolaborasi antara cendekiawan, bisnis, dan pemerintah merupakan langkah utama yang perlu dirumuskan (Departemen Perdagangan, 2008). Industri kreatifmerupakan penggerak penciptaan nilai pada ekonomi kreatif. Dalam prosespenciptaan nilai kreatif, industri kreatif tidak hanya menciptakan transaksiekonomi, tetapi juga transaksi sosial dan budaya. Proses umum yang terjadi dalamrantai nilai kreatif adalah kreasi-produksi-distribusi-komersialisasi, namun setiapkelompok industri kreatif memiliki rantai niali kreatif yang berbeda.

Definisi industri kreatif sendiri menurut Departemen Perdagangan dalam buku Pengembangan Ekonomi Kreatif Indonesia 2025 (2008) adalah: "Kemampuan dari industri kreatif dalam memanfaatkan kreativitas, keterampilan, serta bakat individu untuk menciptakan kesejahteraan serta lapangan pekerjaan melalui penciptaan dan pemanfaatan daya kreasi dan daya cipta individu tersebut".

Badan Ekonomi Kreatif Indonesia telah mengeluarkan sub sektor terbaru dari industri kreatif yaitu sebanyak 16 sub sektor industri kreatif, diantaranya adalah: arsitektur; desain interior; desain komunikasi visual; desain produk; fashion; film, animasi dan video; fotografi; kriya; kuliner; musik; aplikasi dan game developer; penerbitan, periklanan, seni pertunjukan, seni rupa, serta televisi dan radio. (Perpres No. 72 Tahun 2015) 
1. Arsitektur

2. Desain Interior

3. Desain komunikasi visual

4. Desain produk

5. Film, animasi, dan video

6. Fotografi

7. Kriya

8. Kuliner
9. Musik

10. Fashion

11. Aplikasi dan game developer

12. Penerbitan

13. Periklanan

14. Televisi dan radio

15. Seni pertunjukkan

16. Seni rupa

Konsep pariwisata kreatif pada awalnya didasarkan pada pengalaman yang berhubungan dengan wilayah tradisional budaya dan kreativitas belajar. model yang lebih baru telah didasarkan pada integrasi pariwisata dan industri kreatif secara keseluruhan, yang terlibat tidak hanya konsumen tetapi juga produsen, pembuat kebijakan dan lembaga pengetahuan. sektor kreatif seperti desain, fashion, game dan animasi sekarang menyediakan akses ke pasar baru dan diversifikasi permintaan (OECD, 2014).

\section{Metode Penelitian}

Penelitian ini menggunakan metode analisis data deskriptif, dimana metode ini digunakan untuk menjelaskan suatu fenomena yang terjadi. Penelitian deskriptif adalah penelitian yang bertujuan untuk memberikan atau menjabarkan suatu keadaan atau fenomena yang terjadi saat ini dengan menggunakan prosedur ilmiah untuk menjawab masalah secara aktual (Sugiyono,2007). Metode deskriptif digunakan untuk mendeskripsikan, menginterpretasikan sesuatu fenomena, misalnya kondisi atau hubungan yang ada, pendapat yang berkembang, dengan menggunakan prosedur ilmiah untuk menjawab masalah secara actual.

Penelitian ini juga menggunakan metode naratif yang merupakan strategi penelitian dimana di dalamnya peneliti menyelidiki kehidupan individu dan meminta seorang atau kelompok individu untuk menceritakan kehidupan mereka.Menurut Bogdan dan Tylor sebagaimana yang dikutip oleh Moleong (2004) menyebutkan bahwa yang dimaksud dengan deskriptif kualitatif adalah metode yang digunakan untuk menganalisa data dengan mendeskripsikan data melalui bentuk kata-kata tertulis atau lisan dari orang-orang dan prilaku yang diamati.

Unit analisis dalam penelitian ini adalah orang-orang yang mengetahui, berkaitan, dan menjadi pelaku dari industri kreatif seni pertunjukkan Jaranan, diharapkan dapat memberikan informasi. Penentuan informan ini diperoleh dengan cara menerapkan populasi, maksudnya keseluruhan pihak yang ada dalam penelitian berperan sebagai sasaran penelitian.

Informan dipilih berdasarkan pengetahuannya tentang industri kreatif, pariwisata dan kesenian Jaranan di Kota Kediri. Berdasarkan hal tersebut maka informan yang akan dipilih yaitu:

a. Kepala Dinas Koperasi dan UMKM

b. Kepala Dinas Kebudayaan, Pariwisata, Pemuda, dan Olahraga Kota Kediri 

c. Pemilik kelompok seni Jaranan
d. Ketua Paguyuban Kesenian Jaranan Wahyu Kridha Budaya
e. Pengrajin barongan

Teknik pengumpulan data pada penelitian ini menggunakan wawancara, dokumentasi, serta observasi. Sedangkan teknik analisis data pada penelitian ini terdapat 5 tahap yaitu : tahap pertama adalah mengolah data yang diperoleh dari hasil wawancara lapangan, dari hasil wawancara dipilih dan disesuaikan dengan kebutuhan penelitian; tahap kedua data yang sudah diolah akan disesuaikan dengan dokumen yang; tahap ketiga yaitu Setelah melakukan penguraian terhadap data-data penelitian tersebut proses ini biasa dikenal dengan validasi dan reduksi; tahap keempat adalah mengintepretasikan temuan hasil penelitiandengan menggunakan pemaparan argumentatif; sebagai tahap akhir adalah proses verifikasi temuan hasil penelitian dengan teori atau konsep relevan.

\section{Hasil dan Pembahasan}

\section{Pembangunan Industri Kreatif di Kota Kediri}

Pemerintah Kota Kediri telah mencanangkan Tri Bina Kota sebagai acuan dalam melakukan pembangunan yang terdiri dari pendidikan, perdagangan serta jasa serta Industri. Dalam usaha pembangunan sektor industri, Pemerintah Kota Kediri melaksanakan program pengembangan industri. Program pengembangan industri adalah untuk mengembangkan usaha industri dan meningkatkan kapasitas produksinya, khususnya bagi Usaha Mikro Kecil dan Menengah (UMKM) serta keanekaragaman usaha produksi.

Sebagian besar unit usaha UMKM di Kota Kediri bergerak dalam produksi makanan dan pengolahan hasil pertanian. Hal ini dikarenakan wilayah-wilayah penyangga (greater area) di sekitar Kota Kediri merupakan penghasil berbagai komoditas pertanian sehingga banyak pihak yang melihatnya sebagai peluang usaha yang prospektif dan kemudian diolah menjadi produk yang memiliki nilai tambah, bahkan beberapa di antaranya telah berhasil memasarkan produknya menembus pasar internasional.

Menurut data dari Disperinda selama 2012-2015 tahun terakhir UMKM di Kota Kediri mengalami penambahan jumlah.

Tabel 1. Data UMKM 2012-2015

\begin{tabular}{|l|c|c|}
\hline No & Tahun & Jumlah Unit Usaha \\
\hline 1 & 2012 & 21.597 \\
\hline 2 & 2013 & 26.408 \\
\hline 3 & 2014 & 30.379 \\
\hline 4 & 2015 & 31.384 \\
\hline
\end{tabular}

Sumber: Dinas Koperasi dan UMKM Kota Kediri

Berdasar data diatas dapat dilihat bahwa UMKM di Kota Kediri menunjukkan tren yang baik, karena setiap tahunnya jumlah UMKM baru yang muncul semakin banyak. 
Dengan banyak munculnya UMKM baru setiap tahun maka penyerapan tenaga kerja dari tiap pelaku UMKM ini juga akan semakin bertambah, sehingga UMKM mampu membantu kinerja pemerintah Kota Kediri dalam mensejahterakan masyarakat melalui usaha mandiri.

Pemerintah Kota Kediri belum melakukan pemetaan secara khusus untuk industri kreatif yang ada di Kota Kediri, 14 sektor yang termasuk dalam industri kreatif di Kota Kediri belum terdata semua. Dinas Koperasi dan UMKM Kota Kediri hanya mendata UMKM unggulan yang termasuk ke dalam 14 sektor industri kreatif, beberapa diantaranya adalah sektor kuliner, kerajinan, dan fesyen. Seperti yang dikatakan oleh Kristianto Kepala Dinas Koperasi dan UMKM, "Belum ada pemetaan secara khusus untuk industri kreatif tersebut, karena kita masih fokus pada UMKM dan selain itu kita masih rancu dengan Dinas Perdagangan. Di beberapa kasus UMKM binaan kita juga masuk sebagai binaan Dinas Perdagangan”. Kristianto juga menambahkan

"Dinas Koperasi dan UMKM sudah melakukan pendataan tentang UMKM dan beberapa UMKM unggulan di Kota Kediri sudah termasuk ke dalam industri kreatif, seperti kuliner Tahu taqwa dan pembuatan sulak di daerah Blabak yang memiliki kualitas ekspor. Namun beberapa pelaku UMKM yang ikut pelatihan di Klinik UMKM juga berhasil membuat produk hiasan lampu tidur”.

Pernyataan Krintianto ini diperkuat dari Departemen Perdagangan pada studi pemetaan industri kreatif tahun 2007 dalam buku Pengembangan Ekonomi Kreatif Indonesia 2025 (2008), industri kreatif adalah: Industri yang berasal dari pemanfaatan kreativitas, keterampilan, serta bakat individu untuk menciptakan kesejahteraan serta lapangan pekerjaan melalui penciptaan dan pemanfaatan daya kreasi dan daya cipta individu tersebut. UMKM unggulan di Kota Kediri sudah termasuk ke dalam industri kreatif karena memiliki ciri khas serta mampu menyerap tenaga kerja yang berasal dari Kota Kediri.

Pemanfaatan ekonomi lokal dalam UMKM unggulan ini dirasa belum terserap seluruhnya, karena untuk beberapa UMKM bahan baku produksi masih mengambil dari luar Kota Kediri. Peneliti mencoba menggali informasi untuk pemanfaatan ekonomi lokal dalam UMKM unggulan ini, peneliti bertanya "apakah UMKM unggulan sudah mampu memanfaatkan potensi lokal, seperti tenaga kerja maupun bahan baku?". Kristianto mengemukakan bahwa,

"Kebanyakan bahan baku yang diperoleh para pelaku UMKM masih dari luar daerah Kota Kediri, karena UMKM seperti tenun ikat dan batik harus mencari kain dan bahan lainnya di luar Kota Kediri. Sedangkan untuk tenaga kerja, karena kebanyakan UMKM di Kota Kediri masih skala rumahan maka tenaga kerjanya masih kerabat maupun tetangga dimana UMKM tersebut beroperasi”.

Berikut merupakan UMKM unggulan yang berbasis industri kreatif di Kota Kediri yang sesuai dengan faktor-faktor yang termasuk industri kreatif yaitu: 
Tabel 2. UMKM unggulan berbasis ekonomi kreatif Kota Kediri

\begin{tabular}{|c|c|c|c|}
\hline NO & Klasifikasi UMKM & Jenis Produk & Keterangan \\
\hline 1 & $\begin{array}{l}\text { UMKM yang unggul dan } \\
\text { menonjol }\end{array}$ & Tenun ikat, Sulak, Batik & $\begin{array}{l}\text { Daya kreasi: Tinggi } \\
\text { Serapan tenaga kerja: Tinggi } \\
\text { Pemasaran: Tinggi } \\
\text { Bahan Baku: Tinggi } \\
\text { Kebaruan: Tinggi } \\
\text { Pendidikan: Sedang } \\
\text { Lama Usaha: Rendah }\end{array}$ \\
\hline 2 & $\begin{array}{l}\text { UMKM yang unggul dan } \\
\text { cukup }\end{array}$ & $\begin{array}{l}\text { Kerajinan kaos, } \\
\text { kerupuk, toples hias, } \\
\text { jilbab lukis, manik- } \\
\text { manik, aneka bordir, } \\
\text { dan kaca hias }\end{array}$ & $\begin{array}{l}\text { Daya kreasi: Tinggi } \\
\text { Serapan tenaga kerja: Cukup } \\
\text { Pemasaran: Cukup } \\
\text { Bahan Baku: Tinggi } \\
\text { Kebaruan: Tinggi } \\
\text { Pendidikan: Sedang } \\
\text { Lama Usaha: Rendah }\end{array}$ \\
\hline 3 & $\begin{array}{l}\text { UMKM yang unggul dan } \\
\text { kurang }\end{array}$ & Tahu & $\begin{array}{l}\text { Daya kreasi: Rendah } \\
\text { Serapan tenaga kerja: Tinggi } \\
\text { Pemasaran: Tinggi } \\
\text { Bahan Baku: Cukup } \\
\text { Kebaruan: Rendah } \\
\text { Pendidikan: Sedang } \\
\text { Lama Usaha: Tinggi }\end{array}$ \\
\hline
\end{tabular}

Sumber: Dinas Koperasi dan UMKM Kota Kediri

\section{Penyerapan Tenaga Kerja dan Pemanfaatan Ekonomi Lokal Dalam Kesenian Jaranan}

Kota Kediri sebagai kota yang memiliki cerita sejarah yang panjang, sebenarnya memiliki cukup banyak seni pertunjukkan yang hingga saat ini masih beroperasi dan terdata di Dinas Budaya Pariwisata Pemuda dan Olahraga. Beberapa seni pertunjukkan yang ada di Kota Kediri adalah: 
Tabel 3. Seni Pertunjukkan Kota Kediri

\begin{tabular}{|c|l|l|l|l|l|}
\hline No & Jenis Kesenian & $\begin{array}{c}\text { Kecamatan } \\
\text { Mojoroto }\end{array}$ & $\begin{array}{c}\text { Kecamatan } \\
\text { Kota }\end{array}$ & $\begin{array}{c}\text { Kecamatan } \\
\text { Pesantren }\end{array}$ & Jumlah \\
\hline 1 & Jaranan & 43 Grup & 40 Grup & 30 Grup & 113 Grup \\
\hline 2 & Orkes Melayu & 12 Grup & 9 Grup & 15 Grup & 36 Grup \\
\hline 3 & Sanggar Tari & 3 Grup & - & 1 Grup & 4 Grup \\
\hline 4 & Wayang Kulit & 2 Grup & - & 5 Grup & 7 Grup \\
\hline 5 & Campursari & 2 Grup & 1 Grup & 3 Grup & 6 Grup \\
\hline 6 & Jemblung & 1 Grup & - & - & 1 Grup \\
\hline 7 & Reog & - & - & 2 Grup & 2 Grup \\
\hline 8 & Ketoprak & - & 2 Grup & 1 Grup & 3 Grup \\
\hline Jumlah & & 63 Grup & 52 Grup & 57 Grup & 172 Grup \\
\hline
\end{tabular}

Sumber : Dinas Budaya Pariwisata Pemuda dan Olahraga Kota Kediri

Data dari diatas telah menunjukkan bahwa kesenian Jaranan merupakan seni pertunjukkan yang berjumlah paling banyak di Kota Kediri dengan jumlah sebanyak 113 Grup yang sudah memiliki nomor induk, kesenian Jaranan menjadi Seni pertunjukkan paling populer di Kota Kediri. Perkembangan kesenian Jaranan ini semakin berkembang pesat dari tahun ke tahun. Hal ini diperkuat dengan keterangan Yudhi sebagai salah satu pelaku di kesenian Jaranan sejak tahun 1972 bahwa,

"Dulu awal saya masuk di Jaranan kelompok Jaranan masih berjumlah 60 kelompok, lha sekarang sudah ada hampir 120 kelompok di Kota Kediri”.

Daya tarik kesenian Jaranan berakibat kepada makin banyaknya masyarakat yang ikut bergabung dengan kelompok Jaranan, bahkan Yudhi mengungkapkan,

"Untuk mencari 100 pemain Jaranandari Kota Kediri butuh waktu cepat karena banyak sekali masyarakat Kota Kediri yang bersedia untuk tampil saat pertunjukkan Jaranan, bahkan beberapa orang menelpon langsung kepada saya dan karena jumlah pemain sudahtercukupi beberapa pemuda sampai rela sebagai crew maupun sebagai simpatisan hanya saat ada kesenian Jaranan ini tampil”.

Untuk jumlah personel di setiap kelompok Jaranan, Giman mengatakan:

"Setiap kelompok Jaranan biasanya beranggotakan 20 sampai 30 orang semua berasal dari orang Kediri, namun saat pertunjukkan jumlah itu disesuaikan dengan besarnya anggaran dari penyewa. Rata-rata dalam satu kelompok Jaranan terdiri dari: Dalang, gambuh, penari, sindhen, dan nayaga". 
Dilihat dari penyerapan tenaga kerja di Kota Kediri, di dalam kelompok kesenian Jaranan cukup banyak menyerap tenaga kerja. Yang menjadi menarik dari setiap personel di kelompok Jaranan adalah, semua personel Jaranan ini memiliki pekerjaan lain untuk mencukupi kebutuhan hidupnya. Untuk pembagian pendapatan hasil dari pertunjukkan Jaranan setiap pemain biasanya mendapat Rp. 20.000 sampai Rp. 30.000, sedangkan nayaga sebagai pemain gamelan biasanya mendapat Rp. 50.000 sampai Rp. 75.000, namun tidak semua kelompok Jaranan membagi dengan nominal yang sama.

Menurut Hari Pratondo:

"Sekarang kelompok Jaranan membagi pendapatan dari pertunjukkan secara transparan, semua anggota kelompok mengetahui berapa pendapatan saat itu serta apa saja biaya yang dikeluarkan sehingga setiap anggota kelompok tahu mereka dapat upah berapa".

Hal ini diperjelas oleh Deni bahwa:

"Seumpama hari itu pendapatan pertunjukkan Rp. 3.000.000 lalu dikurangi semua biaya sebanyak Rp. 2.000.000, maka sisa pendapatan itu yang akan dibagi rata kepada semua pemain maupun nayaga".

Karena pendapatan dari pertunjukkan jaranan yang kecil, setiap pemain jaranan saat ini sudah pasti memiliki pekerjaan lain, kebanyakan dari para pemain jaranan ini bekerja sebagai buruh pabrik, seperti yang diungkapkan oleh Yudhi yaitu:

"Jaranan sekarang belum bisa dijadikan pekerjaan tetap, setiap pemain pasti punya pekerjaan lain di luar jaranan, ada yang jadi buruh pabrik, buruh bangunan. Jadi ketika ada pertunjukkan tidak bisa sehari dua hari buat persiapan, paling tidak seminggu sebelumnya".

Departemen Perdagangan (2008) adalah kemampuan dari industri kreatif dalam memanfaatkan kreativitas, keterampilan, serta bakat individu untuk menciptakan kesejahteraan serta lapangan pekerjaan melalui penciptaan dan pemanfaatan daya kreasi dan daya cipta individu tersebut. Seiring semakin berkembangnya kesenian Jaranan, berbagai usaha pendukung kesenian Jaranan satu-persatu pun semakin banyak seperti:

\section{Pengrajin ukir barongan di Kelurahan Lirboyo}

Pengrajin barongan ini bernama Nur Khayadi, sudah menjadi pengrajin barongan selama 20 tahun. Menurut Nur Khayadi,

"Bahan baku kerajinan Barongan relatif mudah didapatkan, diperoleh dari lingkungan sekitar Kota Kediri, mulai dari bambu, kulit, ekor lembu untuk rambut, kayu Kayu Dadap Cangkring atau kayu waru, cat, tali plastik dll, khusus untuk kebutuhan kayu bisa diperoleh di kota-kota sekitar Kediri, seperti : Madiun, Nganjuk, Kabupaten Kediri, dll", 


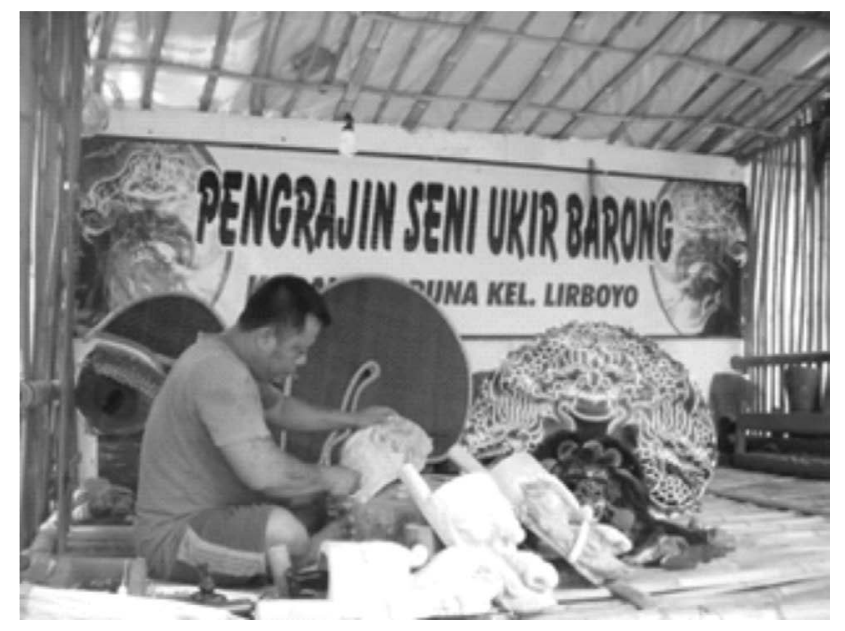

Gambar 1. Pengrajin barongan di Kelurahan Lirboyo

Dibanding dengan rumitnya pengerjaan, harga seperangkat kesenian Jaranan sangatlah relatif dan tidak terlalu mahal, harga 1 set Barongan siap pakai untuk pasar lokal dipatok Rp. 6.450.000 yang terdiri dari :

a. 6 Jaran kepang harga per buah antara Rp. 350.000 - Rp. 400.000;

b. 1 Barongan kualitas standart harga Rp. 1.500.000;

Kualitas super harga Rp. Rp. 2.500.000;

c. 1 kucingan harga per buah Rp. 1.250.000;

d. 1 celeng harga per buah Rp. 300.000 .

Harga tersebut berbeda untuk pesanan luar pulau atau luar negeri kata beliau dikarenakan nilai seni yang berbeda dengan daerah asal, juga jarak dan ongkos pengiriman.

\section{Pengrajin pecut di Kelurahan Jagalan}

Wahyu Ristanto, sudah menjadi pengrajin pecut dan perlengkapan Jaranan sejak tahun 1992. Produknya saat itu membuat Jaranan kuda lumping, Barongan, Pentulan, dan Pecut Jaranan. Pekerja pembuat kuda lumping sebanyak 1 orang; pekerja pembuat pecut 2 orang; pekerja pembuat caplokan 1 orang; dan pekerja pembuat celeng 1 orang. Pekerja yang direkrut berasal dari para pemuda yang menganggur dan putus sekolah. Ada yang lulusan SMP dan ada yang lulusan SMA. Mereka berasal dari Kota Kediri sebanyak 2 orang dan yang lain dari luar Kota Kediri.

Untuk bahan baku didatangkan dari Kota Kediri dan dari luar Kota Kediri. Seperti bahan baku bambu dari Tulungagung, kayu untuk pentulan dari Ponorogo. Datangnya bahan baku setiap satu bulan sekali. Kalau untuk caplokan bahan bakunya dari lokal saja yang dipres dengan cetakan caplokan. Bahan baku pecut juga berasal dari lokal. Waktu pengerjaan biasanya dimulai jam 5 pagi sampai dengan jam 4 sore. Para pekerja akan menyetorkan hasil kerjaannya setiap 2 minggu sekali. Upah yang diterima oleh pekerja berkisar Rp. 300.000 
sampai dengan Rp. 400.000 per-minggunya.

Untuk memenuhi pesanan partai besar, akan dilakukan dengan caramengumpulkannya dari para pengrajinnya yang ada di Kediri (Prambon ada 2 orang pengrajin, Wates ada 2 orang pengrajin, Gampeng ada 2 orang pengrajin, Jagalan ada 2 orang pengrajin) dan luar Kota Kediri (Tulungagung ada 2 orang pengrajin). Skala pesanan bisa mencapai 6.000 kodi untuk Jaranan; 500 kodi untuk pesanan caplokan; 200 kodi pentulan; 6000 kodi pecut. Biasanya jumlah pesanan terbanyak bila memasuki Hari Raya Idul Fitri dan Hari Raya Natal. Pada saat itu pesanan bisa mencapai 10.000 kodi kuda lumping; 5.000 kodi caplokan; 10.000 kodi pecut Jaranan (http://kel-jagalan.kedirikota.go.id/, 2016).

Tidak hanya pengrajin yang semakin banyak, pembeli perlengkapan Jaranan ini tidak terbatas pada kelompok Jaranan saja tapi masyarakat yang memang hobi dengan kesenian Jarananjuga ikut membeli perlengkapan Jaranan sebagai koleksi.

\section{Strategi DalamPengembangan Ekonomi Lokal dan Ekonomi Kreatif Pada Kesenian Jaranan Sebagai Daya Tarik Wisata}

Ekonomi kreatif dan sektor wisata merupakan dua hal yang saling berpengaruh dan dapat saling bersinergi jika dikelola dengan baik (Ooi, 2006). Konsep kegiatan wisata dapat didefinisikan dengan tiga faktor, yaitu harus ada something to see, something to do, dansomething to buy (Yoeti, 1985). Something to see terkait dengan atraksi di daerah tujuan wisata, something to do terkait dengan aktivitas wisatawan di daerah wisata, sementara something to buy terkait dengan souvenir khas yang dibeli di daerah wisata sebagai memorabilia pribadi wisatawan. Dalam tiga komponen tersebut, ekonomi kreatif dapat masuk melalui something to buy dengan menciptakan produk-produk inovatif khas daerah.

Dalam pengembangan ekonomi kreatif melalui sektor wisata yang dijelaskan lebih lanjut oleh Yozcu dan İçöz (2010), kreativitas akan merangsang daerah tujuan wisata untuk menciptakan produk-produk inovatif yang akan memberi nilai tambah dan daya saing yang lebih tinggi dibanding dengan daerah tujuan wisata lainnya.

Tingkat kunjungan wisata di Kota Kediri saat ini, belum banyak mengikutsertakan industri kreatif serta memanfaatkan ekonomi lokal. Berdasar data Dinas Budaya, Pariwisata, Pemuda dan Olahraga, dapat diketahui jumlah kunjungan wisata di Kota Kediri, yaitu :

Tabel 4: Data Kunjungan Wisata Kota Kediri Tahun 2016

\begin{tabular}{|c|c|l|l|l|l|l|l|l|}
\hline \multirow{3}{*}{ Bulan } & \multicolumn{9}{|c|}{$\begin{array}{c}\text { Paya Tarik Wisata } \\
\text { Tirtoyoso }\end{array}$} & \multicolumn{2}{|c|}{\begin{tabular}{c} 
Pemandian Pagora \\
\cline { 2 - 8 }
\end{tabular}} & Wisman & Wisnus & Wisman & Wisnus & Wisman & Wisnus & Wisman & Wisnus \\
\hline Januari & & 18.763 & & 25.764 & & 1.570 & & \multicolumn{2}{c|}{$\begin{array}{c}\text { Goa } \\
\text { Selomangleng }\end{array}$} \\
\hline Pebruari & & 4.011 & & 8.401 & & 148 & & 5.615 \\
\hline
\end{tabular}




\begin{tabular}{|l|l|l|l|l|l|l|l|l|}
\hline Maret & & 11.310 & & 8.240 & & 114 & & 5.414 \\
\hline April & 2 & 9.439 & & 7.064 & & 549 & & 3.964 \\
\hline Mei & & 10.439 & & 8.675 & & 429 & & 3.396 \\
\hline Juni & 5 & 3.429 & & 3.419 & & 214 & & 3.215 \\
\hline Juli 4 & 7.943 & & 5.926 & & 428 & & 7.933 \\
\hline
\end{tabular}

Sumber : Dinas Budaya Pariwisata Pemuda dan Olahraga

Goa Selomangleng sebagai salah satu ikon tempat wisata di Kota Kediri, jumlah kunjungan wisatanya lebih sedikit jumlahnya dibanding Kolam Renang Tirtoyoso. Bahkan kunjungan wisata mancanegara juga lebih banyak di Kolam Renang Tirtoyoso, padahal Goa Selomangleng simbol budaya dan sejarah yang ada di Kota Kediri. Kunjungan di kawasan Goa Selomangleng cukup banyak juga karena adanya kolam renang, ini bisa dilihat dari sedikitnya kunjungan di museum Erlangga

Menurut Nur Muhyar, Kepala Dinas Budaya Pariwisata Pemuda dan Olahraga bahwa,

"Sebenarnya di Goa Selomangleng sudah disediakan tempat bagi pelaku seni untuk menunjukkan karya mereka, terutama untuk kesenian Jaranan sudah dijadwalkan sebulan sekali akan ada pertunjukkan Jaranan".

Namun karena tidak maksimalnya penjadwalannya dan pengaturan dari pemerintah, membuat para pelaku kesenian Jaranan masih melakukan pertunjukkan sesuai dengan "tanggapan" yang mereka terima.Hari Pratondo mengungkapkan

"Hingga saat ini belum ada tempat khusus bagi kesenian Jaranan di Kota Kediri untuk melakukan pertunjukkan, padahal seni pertunjukkan di kota lain seperti di Solo, wayang orang disediakan gedung tersendiri di sekitar tempat wisata Sriwedari".

Padahal dengan adanya tempat khusus untuk pertunjukkan Jaranan dan dilengkapi dengan jadwal pertunjukkan yang diketahui masyarakat, wisatawan mancanegara maupun nusantara akan lebih mudah mengunjungi tempat wisata tersebut.

Tujuan dari pembangunan ekonomi lokal adalah untuk membangun kapasitas ekonomi dari daerah setempat untuk memperbaiki masa depan ekonomi dan kualitas hidup untuk semua. Ini adalah proses dimana publik, bisnis dan non-pemerintah mitra sektor bekerja secara kolektif untuk membuat lebih baik kondisi untuk pertumbuhan ekonomi dan penciptaan lapangan kerja (Swinburn et al, 2006). Untuk lebih mengatur keberadaan kesenian Jaranan sebagai salah satu industri kreatif dan ikon Kota kediri,beberapa hal telah dilakukan pemerintah Kota Kediri yaitu :

1. Memberikan no induk anggota

Menurut keterangan dari Yudhi 
"Sejak tahun 2013 setiap kelompok Jaranan sudah diberi nomor induk anggota, sehingga ketika pemerintah memiliki event pemerintah tahu jumlah anggota Jaranan di Kota kediri”.

Dari no induk anggota ini pula dapat diketahui jika ada masalah dalam kelompok Jaranan dan seluruh anggota paguyuban Jaranan Kota Kediri tahu apa yang harus dibantu.

2. Mengikutkan dalam event-event tahunan Kota Kediri

Sejak tahun 2010 pemerintah Kota Kediri sudah menjadwalkan berbagai event yang pasti mengikutsertakan kesenian Jaranan, hal ini diungkapkan oleh Nur Muhyar yaitu,

"Tahun ini ada beberapa event yang mengikutsertakan kesenian Jaranan seperti Grebeg Sura, Pagelaran Jaranan Nusantara, Parade Jaranan, hingga pertunjukkan Jaranan techno. Dan event-event ini akan menjadi agenda tahunan Kota Kediri”.

3. Mematenkan Kesenian Jaranan

Usaha untuk mematenkan kesenian Jaranan sebagai kesenian khas Kediri sudah pernah dilakukan oleh pemerintah Kota Kediri, hal ini seperti yang disampaikan Nur Muhyar,

"Pemerintah sudah pernah mencoba untuk mematenkan kesenian Jaranan, namun karena kesenian Jaranan memiliki banyak kesamaan dengan kesenian kuda lumping di berbagai daerah dan Jaranan di Kediri belum memiliki pakem khusus maka usaha untuk mencari pakem gagal".

Hari Pratondo Sebagai Ketua Paguyuban Jaranan Kota kediri Wahyu Kridha Budaya, memiliki pandangan dan masukan kepada semua pihak yang berhubungan langsung dengan kesenian Jaranan. Strategi yang harus dilakukan agar kelestarian kesenian Jaranan tetap terjaga dan mampu memjadi dayatarik wisata Kota Kediri, beberapa hal tersebut yaitu :

\section{Penataan Penampilan}

Hal pertama yang harus dilakukan dalam upaya pelestarian kesenian Jaranan adalah penataan penampilan. Sebagai penentu sebuah pertunjukkan diminati atau tidak adalah masyarakat sendiri, karena masyarakat adalah konsumen atau pengguna (penanggap) dari jasa hiburan. Kelompok Jaranan yang laris mendapat tanggapan adalah kelompok yang memiliki kelebihan tertentu seperti penampilan yang bagus, harga yang kompetitif, dan pemasaran yang bagus. Diantara tida syarat tersebut penampilan yang bagus yang menjadi utama (Huda, 2016).

2. Identitas dan ikon Kediri

Setiap tempat memiliki identitas dan iklim daerahnya-daerahnya sendiri-sendiri. Kedua hal tersebut menjadi pembeda dan ciri khas daerah tersebut dibanding daerah lain. Beberapa daerah telah mampu menggunakan kesenian khas daerahnya sebagai penanda 
khas daerahnya serta menjadi daya pikat pariwisata.

Untuk mampu menjadi daya tarik wisata suatu daerah, dibutuhkan konsistensi serta inovasi dari pemerintah daerah untuk mewujudkannya. Rencana strategis pembangunan ekonomi lokal biasanya dilakukan oleh pemerintah daerah dalam hubungannya dengan publik dan swasta. Implementasi dilakukan oleh masyarakat, swasta dan sektor nonpemerintah sesuai dengan kemampuan dan kekuatan mereka (Swimburn et al, 2006).

Penonjolan Jaranan sebagai identitas dan ikon Kediri bisa dilakukan dengan menjadikan Jaranan sebagai ragam hias lokal yang muncul pada batik dan ornamen hiasan arsitektur bangunan publik. Gambar-gambar Jaranan seharusnya bisa digunakan sebagai souvenir dengan desain yang menarik sehingga dapat menarik minat masyarakat.

Kediri telah identik dengan Jaranan, sudah banyak pengrajin maupun penjual asesoris Jaranan sebagai cinderamata khas daerah. Terdapat trend baru dikalangan pemuda, yaitu mereka dengan bangga berkalung udeng ketika berada dimanapun. Satu hal yang perlu ditekankan kepada berbagai pihak adalah menanamkan kesan bahwa Jaranan sebagai kesatuan dari pariwisata Kota Kediri sehingga tercipta pemikiran tidak lengkap berkunjung ke Kediri tanpa melihat Jaranan (Huda, 2016).

\section{Gedung Pertunjukkan}

Menyediakan tempat untuk menggelar pertunjukkan kesenian Jaranan secara berkala dan terjadwal serta dipublikasikan secara luas melalui media massa maupun internet, akan memudahkan masyarakat luar daerah untuk melihat pertunjukkan Jaranan secara langsung.

Selama ini kesenian Jaranan memang secara berkala telah ditampilkan dibeberapa obyek wisata yang ada di Kota Kediri seperti, Goa Selomangleng, Taman Wisata Pagora. Namun semua pertunjukkannya tanpa fasilitas pendukung, serta tidak adanya bangku tempat duduk bagi penonton untuk menikmati pertunjukkan dengan nyaman.

Sudah saatnya Kediri memiliki gedung pertunjukkan kesenian Jaranan yang representatif dengan obyek-obyek wisata yang ada di Kota Kediri. Dengan cara ini wisatawan yang berkunjung ke Kota Kediri mendapat paket wisata yang lengkap, selain berkunjung ke obyek wisata sejarah dan kuliner wisatawan juga mendapat pertunjukkan Jaranan (Huda, 2016).

Dengan adanya gedung pertunjukkan khusus kesenian Jaranan, setiap kelompok Jaranan dapat diberdayakan mereka secara bergantian diberi kesempatan untuk tampil bergiliran pada waktu tertentu dengan strandar penampilan yang sudah ditentukan bersama. Selain memberikan kesempatan kepada kelompok Jaranan, keberadaan gedung pertunjukkan juga memberikan kesempatan kepada para pengrajin asesoris untuk memasarkan hasil karyanya, dan dapat menjalin kerjasama dengan sponsor maupun agen travel wisata di seluruh Indonesia. 
4. Masuk ke Kurikulum Sekolah

Adanya muatan lokal (Mulok) pada kurikulum sekolah memang memungkinkan untuk itu. Sudah banyak contoh kesenian daerah sudah menjadi jurusan pada sekolam kejuruan maupun perguruan tinggi, sebagai contoh seni pendhalangan, seta kriya seni pada pada jurusan di Institut Seni Indonesia.

Masuknya kesenian jaranan kedalam lingkup akademik akan menciptakan suatu hal yang besar bagi pelestarian kesenian jaranan. Generasi muda akan dikenalkan sejak awal terhadapa kesenian jaranan ini. Dengan menjadi bagian dalam pendidikan ciri khas kesenian jaranan akan tetap terjaga, hingga akhirnya dalam pertunjukkan jaranan dapat memanfaatkan kecanggihan terknologi terkini, jaranan akan bisa ditampilkan secara tak biasa. Laser dan efek-efek pertunjukkan modern akan menciptakan pertunjukkan jaranan yang luar biasa.

\section{Publikasi Media}

Jaranan seharusnya mendapat porsi yang cukup dalam pemberitaan di media massa. Media massa, baik cetak maupun elektronik seharusnya memiliki tanggung jawab untuk membesarkan jaranan. Melalui pemberitaan media yang positif dan menarik jaranan akan dikenal secara luas oleh masyarakat. Jika sudah mampu menarik perhatian masyarakat, akan timbul keinginan untuk melihat pertunjukkan jaranan. Dapat dipastikan muncul keinginan untuk mementaskan jaranan atau akan datang ke Kediri untuk melihat pementasan jaranan.

Perkembangan dan inovasi yang dilakukan oleh para seniman juga pantas untuk ditampilkan di media massa. Melalui pemberitaan media massa, juga dapat memberi apresiasi kepada seniman jaranan untuk terus bersemangat untuk tetap melestarikan kesenian jaranan.

\section{Kesimpulan}

Kota Kediri merupakan salah satu kota di Jawa Timur yang memiliki aset pariwisata yang cukup potensial untuk dikembangkan, baik obyek wisata alam, budaya dan sejarah. Sebagai daya tarik wisata pemerintah Kota Kediri telah mengelompokkan UMKM yang berbasis ekonomi kreatif, dimana UMKM ini menjadi produk unggulan Kota Kediriyang terdiri dari UMKM kuliner hingga kerajinan.

Kesenian jaranan sebagai salah satu industri kreatif di Kota Kediri mampu bertahan diantara berkembangnya teknologi yang telah masuk dalam kehidupan masyarakat. Kesenian jaranan saat ini sudah menjadi salah satu bagian dari kehidupan masyarakat Kota Kediri, hal ini terbukti dari dari tahun ke tahun jumlah kelompok jaranan semakin bertambah banyak, selain itu keberadaan jaranan juga menarik minat masyarakat untuk ikut serta dalam kelompok jaranan hingga ikut menjadi penari jaranan saat pertunjukkan.

Kesenian jaranan hingga saat ini memang belum bisa menjadi sumber penghasilan bagi anggota kelompok jaranan, karena pendapatan yang dihasilkan dari sekali pertunjukkan 
ketika sudah dibagi kepada seluruh anggota hasilnya kecil. Selain itu para anggota kesenian jaranan sudah menganggap bergabung ke dalam kelompok jaranan hanya penyaluran hobi sedangkan hasil yang diperoleh hanya sebagai nilai tambah dari penyaluran hobi tersebut.

Pengembangan ekonomi lokal dengan berkembangannya kesenian jaranan sangat terasa bagi bidang usaha lain, selain para pengrajin perlengkapan dan asesoris jaranan yang semakin bertambah, pedagang kaki lima juga mendapat dampak baik dari ramainya penonton saat pertunjukkan jaranan.

Masih perlu adanya kerjasama yang baik antara pemerintah, pelaku seni, dengan masyarakat agar kesenian jaranan dapat maksimal menjadi daya tarik wisata. Perlu tempat dan cara memasarkan secara khusus wisatawan yang datang ke Kota Kediri mendapat paket wisata yang lengkap selain wisata sejarah, kuliner, serta mendapat pertunjukkan seni layaknya pertunjukkan seni tari di Bali dan pertunjukkan angklung di Bandung.

\section{DAFTAR PUSTAKA}

Departemen Perdagangan RI, 2008, Pengembangan Ekonomi Kreatif Indonesia 2025: Rencana Pengembangan Ekonomi Kreatif Indonesia 2009 - 2015

Fandeli, Chafid. 2001. Dasar-dasar Manajemen Kepariwisataan Alam. Liberty.Yogyakarta

Fristia, V.F. dan Navastara, A.M. 2014. Faktor Penyebab Belum Berkembangnya Industri Kecil Batik Desa Kenongo Kecamatan Tulangan-Sidoarjo. Surabaya : Jurusan Perencanaan Wilayah dan Kota, Institut Teknologi Sepuluh Nopember

Helmsing, A.H.J. (2001) Local Economic Development: New Generations of Factors, Policies and Instruments.Paper dipresentasikan pada Cape Town Symposium.

Huda, Arief Syaifuddin (2016). Kesenian Agung Jaranan Kediri, Kediri: HAPRAINDONESIA

Instruksi presiden republik indonesia. Nomor 16 tahun 2005. Tentang. Kebijakan pembangunan kebudayaan dan pariwisata

Musanef. 1995. Manajemen Usaha Pariwisata di Indonesia. Jakarta : PT TokoGunung Agung

Moleong, Lexy. J. 2004. Metode Penelitian Kualitatif. Remaja Rosdakarya.Bandung

Ooi, Can-Seng.(2006). Tourism and the Creative Economyin Singapore. Denmark:Department of International Economics and Management Copenhagen BusinessSchool

Pedrana M., Regional Science Inquiry Journal, Vol. V, (1), 2013, pp. 91-99

Perpres Nomor 72 Tahun 2015 tentang Perubahan Atas Peraturan Presiden Nomor 6 Tahun 2015 Tentang Badan Ekonomi Kreatif

Sugiyono. 2007. “Metode Penelitian Kuantitatif Kualitatif dan R\&D”. Bandung:Alfabeta 
Swinburn, Gwen, Soraya Goga dan Fergus Murphy (2006). Local economicdevelopment: a primer developing and implementing local economicDevelopment strategies and action plans. Bertelsmann Stiftung, Gütersloh; The World Bank,Washington, D.C.

Yoeti, Oka A (1985). Pengantar Ilmu Pariwisata, Bandung: Angkasa

Yozcu, Özen Kırant dan İçöz, Orhan. (2010). A Model Proposal on the Use of CreativeTourism Experiences in Congress Tourism and the Congress Marketing Mix.PASOS, Vol. 8(3) Special Issue 2010.

https://ardana45.wordpress.com/2013/05/15/pengembangan-ekonomi-kreatif-sebagaipenggerak-industry-pariwisata-bali/, diakses 20 September 2016

http://kel-jagalan.kedirikota.go.id/, diakses 21 September 2016 